\title{
Immediate impact of radiologic technologists in interventional cardiology - single-center experience
}

\author{
(D) Mario Josipović*, \\ (i) Ivan Horvat, \\ (D) Matea Podvorec, \\ (DLucija Lovreković, \\ (D)Jadranka Daskijević, \\ (DIvica Benko
}

University Hospital Centre „Sestre milosrdnice“, Zagreb, Croatia

RECEIVED:

February 19, 2020

ACCEPTED:

February 22, 2020

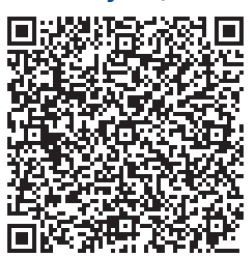

$\square$ Cardiologia Croatica 2020;15(3-4):64.
KEYWORDS: radiologic technologist, radiation, protection.

CITATION: Cardiol Croat. 2020;15(3-4):64. | https://doi.org/10.15836/ccar2020.64

*ADDRESS FOR CORRESPONDENCE: Mario Josipović, KBC Sestre milosrdnice, Vinogradska cesta 29, HR-10000 Zagreb, Croatia. / Phone: +385-98-9555-026 / E-mail: josipovic.mario@hotmail.com

ORCID: Mario Josipović, https://orcid.org/0000-0001-6895-4335 • Ivan Horvat, https://orcid.org/0000-0002-0480-7341 Matea Podvorec, https://orcid.org/0000-0001-7733-2650 • Lucija Lovreković, https://orcid.org/0000-0001-9789-6891 Jadranka Daskijević, https://orcid.org/0000-0001-6547-1098 • Ivica Benko, https://orcid.org/0000-0002-1878-0880

IIIIIIIIIIIIIIIIIIIIIIIIIIIIIIIIIIIIIIIIIIIIIIIIIIIIIIIIIIIIIIIIIIIIIIIIIIIIIIIIIIIIIIIIIIIIIIIIIIIIIIIIIIIIIIII

Introduction: Although radiologic technologists have many responsibilities in the cardiac catheterization laboratory, the most important responsibility is to perform invasive cardiac surgery using radiological equipment in a safe manner, both for staff and for the patient. Very often, in addition to working with radiological equipment, radiologic technologists must have specific knowledge of specific interventional procedures in invasive. In order to monitor the complexity of today's procedures and actively participate in an invasive team, ongoing and specific education is essential. The job of a radiologic technologist in the cardiology intervention room consists of a series of tasks such as: knowledge of the complexity of radiation protection, knowledge of heart anatomy, physiology, hemodynamics and all the technical capabilities of devices used in invasive cardiac methods. At the catheterization laboratory, radiologic technologists participate in preparing the patient for the procedure, which includes checking patient data, taking anamnestic data related to the procedure, placing the patient on the table, monitoring vital functions, etc. ${ }^{1}$ The paper presents the experience of University Hospital Center "Sestre milosrdnice", whereby after the establishment of the Clinic for Cardiovascular Diseases, the team settings at the Department of Invasive and Interventional Cardiology were changed. In earlier periods, practically from the moment the laboratory started with work, the radiological device was operated traditionally and habitually, but also due to a lack of staff, by invasive cardiologists and/ or perioperative nurses. Goal: To compare radiation exposure before and after changes in team settings, and to determine the immediate impact of the work of radiologic technologists in the invasive cardiology laboratory.

Conclusion: Radiologic technologists who directly control radiological equipment and accurately follow the instructions of the operator (interventional cardiologist), by standardizing procedures, can significantly affect the safety of the patient and team in the invasive laboratory.

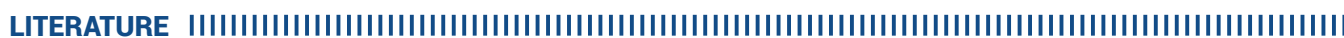
1. Klanfar Z i sur. Radiološke i nuklearno-medicinske dijagnostičke metode. Zdravstveno veleučilište, Zagreb, 2013. 